\title{
KORPORASI DALAM PERSPEKTIF SUBYEK HUKUM PIDANA
}

\author{
Amirullah \\ Fakultas Syariah IAIN Sunan Ampel Surabaya
}

\begin{abstract}
Abtraksi; Korporasi adalah perikatan beberapa orang yang bersepakat dengan tujuan mencari keuntungan dan diakui keberadaannya secara hukum (berbadan hukum). Korporasi sebagai subyek hukum pidana dapat dipersamakan dengan manusia. Karena di dalamnya terdapat hak dan kewajiban yang diberikan oleh hukum, dan karenanya kecakapan korporasi juga dipersamakan dengan kecakapan manusia yang terlibat di dalamnya. Pembahasan pokok hukum pidana mencakup tiga aspek, yaitu I) perbuatan, 2) pertanggungjawaban, dan 3) pidana (sanksi yang diberikan terhadap pelanggar hukum). Secara terori dan praktis ketiganya merupakan unsur yang terpisah dan berbeda satu sama lain. Seseorang dinyatakan telah melanggar hukum pidana apabila perbuatan yang dilakukan tidak sesuai dan bertentangan dengan norma hukum yang telah termaktub dalam perundang-undang yaitu Kitab Undang-undang Hukum Pidana. Pada dasarnya asas legalitas lazim disebut juga dengan terminologi "principle of legality", "legaliteitbeginsel", "non-retroaktif", "de la legalite" atau "ex post facto laws". Ketentuan asas legalitas diatur dalam Pasal I ayat (I) Kitab Undang-Undang Hukum Pidana (KUHP) Indonesia yang berbunyi: "Tiada suatu peristiwa dapat dipidana selain dari kekuatan ketentuan undang-undang pidana yang mendahuluinya." (Geen feit is strafbaar dan uit kracht van een daaran voorafgegane wetteljke strafbepaling).
\end{abstract}

Kata Kunci: Korporasi, Hukum, Pidana, Legalitas.

\section{Pendahuluan}

Pembahasan pokok hukum pidana mencakup tiga aspek, yaitu 1) perbuatan, 2) pertanggungjawaban, dan 3) pidana (sanksi yang diberikan terhadap pelanggar hukum). Secara terori dan praktis ketiganya merupakan unsur yang terpisah dan berbeda satu sama lain. Seseorang dinyatakan telah melanggar hukum pidana apabila perbuatan yang dilakukan tidak sesuai dan 
bertentangan dengan norma hukum yang telah termaktub dalam perundang-undang yaitu Kitab Undang-undang Hukum Pidana. Ketentuan ini tertuang dalam pasal 1 ayat 1: "Tiada suatu perbuatan boleh dihukum, melainkan atas kekuatan ketentuan pidana dalam undang-undang, yang terdahulu dari pada perbuatan itu" ${ }^{1}$

Ketentuan pasal ini menegaskan bahwa hukum pidana Indonesia menganut asas legalitas. Pada dasarnya asas legalitas lazim disebut juga dengan terminologi "principle of legality", "legaliteitbeginsel", "non-retroaktif", "de la legalite" atau "ex post facto laws". Ketentuan asas legalitas diatur dalam Pasal 1 ayat (1) Kitab Undang-Undang Hukum Pidana (KUHP) Indonesia yang berbunyi: "Tiada suatu peristiwa dapat dipidana selain dari kekuatan ketentuan undang-undang pidana yang mendahuluinya." (Geen feit is strafbaar dan uit kracht van een daaran voorafgegane wetteljke strafbepaling). P.A.F. Lamintang dan C. Djisman Samosir merumuskan dengan terminologi sebagai, "Tiada suatu perbuatan dapat dihukum kecuali didasarkan pada ketentuan pidana menurut undang-undang yang telah diadakan lebih dulu". ${ }^{2}$ Andi Hamzah menterjemahkan dengan terminologi, "Tiada suatu perbuatan (feit) yang dapat dipidana selain berdasarkan kekuatan ketentuan perundang-undangan pidana yang mendahuluinya" ${ }^{3}$

Moeljatno menyebutkan pula bahwa, "Tiada suatu perbuatan dapat dipidana kecuali atas kekuatan aturan pidana dalam perundangundangan yang telah ada, sebelum perbuatan dilakukan". ${ }^{4}$ Oemar Seno Adji menentukan prinsip "legality" merupakan karakteristik yang essentieel, baik ia dikemukakan oleh "Rule of Law" - konsep, maupun oleh faham "Rechtstaat" dahulu, maupun oleh konsep

I R. Soesilo, Kitab Undang-undang Hukum Pidana, Ctk. Ulang, Politeia, Bogor, I996, hlm. 27

2 P.A.F. Lamintang dan Djisman Samosir, Hukum Pidana Indonesia, Sinar Baru, Bandung, 1990, hlm. I

${ }^{3}$ Andi Hamzah, Asas-Asas Hukum Pidana, Yarsif Watampone, Jakarta, 2005, hlm. 4I dan:Andi Hamzah, Naskah Akademik Rancangan Undang-Undang Kitab Undang-Undang Hukum Acara Pidana, Paper Panel Diskusi 27 tahun KUHAP, Indonesia Room, Hotel Shangri-La, Jakarta, 26 Nopember 2008, hlm. 12

${ }^{4}$ Moeljatno, Kitab Undang-Undang Hukum Pidana, PT Bumi Aksara, Jakarta, 200 I, hlm. 3 
"Socialist Legality". Demikian misalnya larangan berlakunya hukum Pidana secara retroaktif atau retrospective, larangan analogi, berlakunya azas "nullum delictum" dalam Hukum Pidana, kesemuanya itu merupakan suatu refleksi dari prinsip "legality". ${ }^{5}$

Nyoman Serikat Putra Jaya, menyebutkan perumusan asas legalitas dalam Pasal 1 ayat (1) KUHP mengandung makna asas lex temporis delicti, artinya undang-undang yang berlaku adalah undang-undang yang ada pada saat delik terjadi atau disebut juga asas "nonretroaktif", artinya ada larangan berlakunya suatu undang-undang pidana secara surut. Asas legalitas juga berkaitan dengan larangan penerapan ex post facto criminal law dan larangan pemberlakuan surut hukum pidana dan sanksi pidana (nonretroactive application of criminal laws and criminal sanctions). 6

Karena itu tidak cukup hanya karena perbuatan yang terbukti seseorang dikenakan pidana, tetapi harus ada kesalahannya. Sebuah adagium menyatakan actus non facit reum, nisi mens sit rea (perbuatan tidak membuat orang bersalah kecuali jika terdapat sikap batin yang salah). ${ }^{7}$ Hal ini menegaskan bahwa pernyataan terhadap seseorang telah melanggar hukum pidana dan dikenakan sanksi harus memenuhi dua syarat pokok:

1. Orang tersebut terbukti secara sah dan meyakinkan bahwa ia benar-benar telah melakukan suatu tindak pidana, dan

2. Pada saat orang tersebut melakukan tindak pidana harus dibuktikan bahwa ia benar-benar merupakan orang yang dapat dipertanggung jawabkan secara pidana. ${ }^{8}$

${ }^{5}$ Oemar Seno Adji, Peradiolan Bebas Negara Hukum, Erlangga, Jakarta, 1980, hlm. 21

${ }^{6}$ Nyoman Serikat Putra Jaya, Beberapa Pemikiran Ke Arah Pengembangan Hukum Pidana, PT Citra Aditya Bakti, Bandung, 2008, hlm. 12

7 Teguh Prasetyo dan Abdul Halim Barkatullah, Politik Hukum Pidana, Ctk. Pertama, Pustaka Pelajar, Yogyakarta, 2005, hlm. 54

${ }^{8}$ Abdul Kholiq, Hukum Pidana (Buku Panduan Kuliah), Fakultas Hukum Universitas Islam Indonesia, Yogyakarta, 2002, hlm. 23

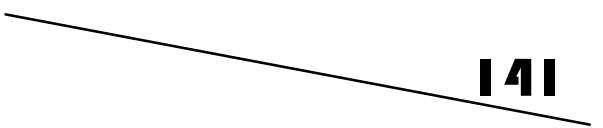


Namun demikian, perdebatan tentang perbuatan yang telah diatur perundangan-undangan juga melahirkan pertanyaan lanjutan, yakni tentang siapa yang melakukan perbuatan pidana. Karenanya asumsi dasar adalah pertanggungjawaban perbuatan pidana hanya dapat dilakukan oleh manusia yang mempunyai kehendak atau keinsyafan untuk melakukannya. Manusia dengan perbuatanya merupakan satu kesatuan yang ditimbulkan oleh hak dan kewajibannya, dalam hal ini menyangkut perbuatan hukum yang telah diatur berdasarkan perundangan-undangan.

Menarik untuk dikaji lebih dalam tentang bagaimana sebenarnya koorporasi subyek dapat menjadi subyek hukum pidana. Karena Hukum pidana Indonesia menganut asas kesalahan yang merupakan dasar untuk menerapkan pertanggung jawaban pidana kepada pelaku yang melanggar ketentuan hukum pidana. Untuk dapat memidana pelaku delik, selain membuktikan unsur-unsur perbuatan yang menimbulkan celaan, dalam diri pelaku harus ada unsur kesalahan. ${ }^{9}$ Sementaar kesalahan merupakan keadaan jiwa dari si pembuat dan hubungan batin antara si pembuat dengan perbuatannya, keadaan jiwa dari seseorang yang melakukan perbuatan merupakan apa yang lazim disebut sebagai kemampuan bertanggung jawab, sedang hubungan batin antar si pembuat dengan perbuatanya itu merupakan kesengajaan, kealpaan serta tiada alasan pemaaf ${ }^{10}$.

Berdasarkan itu, untuk menentukan adanya kesalahan sebagai dasar dari pertanggungjawaban pidana harus memenuhi unsur-unsur sebagai berikut: ${ }^{11}$

1. Adanya kemampuan bertanggungjawab pada si pembuat. Menurut para ahli sarjana bahwa untuk adanya kemampuan bertanggung jawab harus ada. ${ }^{12}$

\footnotetext{
${ }^{9}$ Abdul Kholiq, " ........", artikel pada Jurnal hukum, edisi no. 26 vol. II , 1999. hlm I5

${ }^{10}$ Muladi dan Dwidja Priyatno, op.cit., hlm. 60

"Teguh Prasetyo dan Abdul Halim Barkatullah, op.cit, hlm. 62

${ }^{12}$ Moeljatno, op.cit., hlm. 165
} 
a) Kemampuan untuk membeda-bedakan antara perbuatan yang baik dan buruk: yang sesuai hukum dan yang melawan hukum

b) Kemampuan untuk menentukan kehendaknya menurut keinsyafan tentang baik buruknya perbuatan tadi

2. Hubungan antara batin pelaku dengan perbuatannya yang berupa kesengajaan (Dolus), atau kealpaan (Culpa) ini disebut bentuk-bentuk kesalahan

3. Tidak adanya alasan penghapus kesalahan atau tidak ada alasan pemaaf. ${ }^{13}$ Pasal 44 KUHP menentukan "Barangsiapa melakukan perbuatan yang tidak dapat dipertanggung jawabkan padanya, disebabkan jiwanya cacat dalam tubuhnya atau tergangu karena penyakit tidak dipidana". Menurut pasal tersebut maka hal tidak mampu bertanggung jawab adalah karena hal-hal tertentu, yaitu jiwa yang cacat dalam pertumbuhannya atau terganggu karena penyakit, dan sebagai akibatnya ia tidak mampu mempertanggung jawabkan perbuatannya. Dengan terpenuhi semua unsur di atas, maka seseorang dapat dijatuhi suatu sanksi pidana yang telah ditentukan oleh peraturan perundang-undangan.

Namun demikian, tindak pidana (crime) dapat diidentifikasi dengan timbulnya kerugian (harm), yang kemudian mengakibatkan lahirnya pertanggungjawaban pidana atau criminal liability. ${ }^{14}$ Pada gilirannya mengundang perdebatan adalah bagaimana pertanggungjawaban korporasi atau corporate liability mengingat bahwa di dalam Kitab Undang-undang Hukum Pidana (KUHP) Indonesia menentukan bahwa sebagai subyek hukum pidana hanyalah orang perseorangan dalam konotasi biologis yang alami (naturlijkee person). Di samping itu, KUHP juga masih menganut asas sociates delinquere non potest dimana badan hukum atau korporasi dianggap tidak dapat melakukan tindak

\footnotetext{
${ }^{13}$ Muladi dan Dwidja Priyatno, loc.cit.

${ }^{14}$ Hyman Gross, A Theory of Criminal Justice, Oxford University Press, New York, 1979, hal. I 4
}

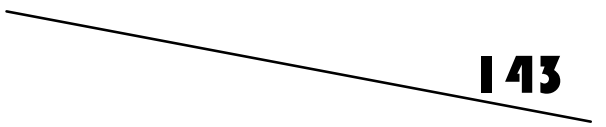


pidana. ${ }^{15}$ Jika seandainya kegiatan atau aktivitas yang dilakukan untuk dan atas nama suatu korporasi terbukti mengakibatkan kerugian dan harus diberikan sanksi, siapa yang akan bertanggungjawab? Apakah pribadi korporasi itu sendiri atau para pengurusnya? Padahal hakikat koorporasi tidak dapat melakukan perbuatan, dan kalau koorporasi melakukan sesuatu hanya karena di dalamnya terdapat peranta perbuatan perikatan manusia secara keperdataan.

\section{Konsep Koorporsi}

Secara etimologis, pengertian korporasi dalam istilah lain dikenal dengan corporatie (Belanda), corporation (Inggris), korporation (Jerman), berasal dari bahasa latin yaitu "corporatio". "Corporatio" sebagai kata benda (subatantivum) berasal dari kata kerja "coporare" yang banyak dipakai orang pada jaman abad pertengahan atau sesudah itu. "Corporare" sendiri berasal dari kata "corpus" (badan), yang berarti memberikan badan atau membadankan. Dengan demikian, maka akhirnya "corporatio" itu berarti hasil dari pekerjaan membadankan, dengan kata lain badan yang dijadikan orang, badan yang diperoleh dengan perbuatan manusia sebagai lawan terhadap badan manusia, yang terjadi menurut alam". 16

Ada beberapa definisi yang dikemukakan mengenai korporasi. Menurut Sutan Remi Sjahdeini, korporasi dapat dilihat dari artinya yang sempit, maupun artinya yang luas. Kemudian Sutan Remi Sjahdeini mengungkapkan bahwa :

"Menurut artinya yang sempit, yaitu sebagai badan hukum, korporasi merupakan figur hukum yang eksistensi dan kewenangannya untuk dapat atau berwenang melakukan perbuatan hukum diakui oleh hukum perdata. Artinya, hukum perdatalah yang mengakui "eksistensi"

\footnotetext{
15 Rusmana,SH, Pertanggungjawaban Korporasi dalam Tindak Pidana Perikanan, http://www.solusihukum.com/artikel/artikel45.php

16 Soetan. K. Malikoel Adil dalam Muladi dan Dwidja Priyatno, Pertanggungjawaban KorporasiDalam Hukum Pidana, STHB, Bandung, 1991, hal. 83
} 
korporasi dan memberikannya "hidup" untuk dapat berwenang melakukan perbuatan hukum sebagai suatu figur hukum. Demikian juga halnya dengan "matinya" korporasi. Suatu korporasi hanya "mati" secara hukum apabila "matinya" korporasi itu diakui oleh hukum". ${ }^{17}$

Istilah korporasi dalam hukum Indonesia atau biasa disebut Perseroan Perdata hanya dikenal dalam Hukum Perdata. Dalam Pasal 1654 Kitab Undang-Undang Hukum Perdata, disebutkan bahwa Korporasi dapat didefinisikan sebagai: "Perseroan perdata adalah suatu persetujuan antara dua orang atau lebih, yang berjanji untuk memasukkan sesuatu ke dalam perseroan itu dengan maksud supaya keuntungan yang diperoleh dari perseroan itu dibagi di antara mereka."

Berdasarkan penjelasan ini, maka korporasi sejak awal telah dikenal dalam hukum perdata dan telah didudukan sebagai subyek hukum. Terdapat dua macam Subyek Hukum dalam pengertian hukum perdata adalah:

a. Natuurlijke Persoon (natural person) yaitu manusia pribadi (Pasal 1329 KUHPerdata).

b. Rechtspersoon (legal entitle) yaitu badan usaha yang berbadan hukum (Pasal 1654 KUHPerdata).

Oleh karena itu konsep korporasi dalam hukum perdata telah berkedudukan sama/dipersamakan dengan manusia sebagai subyek hukum. Karenanya terhadap orang dan korporasi sebagai badan hukum dapat melakukan penuntutan dan atau dituntut secara hukum. Hal ini menegaskan bahwa hukum perdatalah yang telah membentuk korporasi sebagai subyek hukum.

\section{Korporasi dalam Perspektif Subyek Hukum Pidana}

Subyek hukum adalah segala sesuatu yang dapat mempunyai hak $^{18}$ dan kewajiban ${ }^{19}$ untuk bertindak dalam hukum. Sementara Obyek hukum adalah segala sesuatu berguna bagi subyek hukum

\footnotetext{
17 Sutan Remi Sjahdeini, Pertanggungjawaban Pidana Korporasi, Grafiti Pers, Jakarta, hal. 43

${ }^{18}$ Hak adalah kekuasaan, kewenangan yang diberikan oleh hukum kepada subyek hukum

${ }^{19}$ Kewajiban adalah beban yang diberikan oleh hukum kepada subyek hukum
}

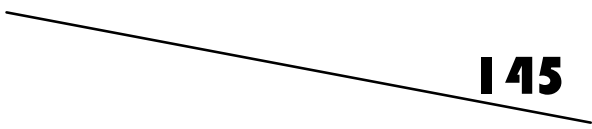


dan dapat menjadi pokok suatu hubungan hukum yang dilakukan oleh subyek hukum. Berdasarkan pengertian ini dapat ditelaah lebih jauh tentang korporasi sebagai subyek hukum pidana.

Korporasi mulai memasuki lingkup Hukum Pidana sebagai subyek hukum sejak munculnya fenomena corporate crime. Fenomena ini mulai muncul di negara maju pada abad ke 19. Kejahatan Korporasi sendiri dapat didefinisikan sebagai: ${ }^{20}$ "...crimes committed either by a corporation (i.e., a business entity having a separate legal personality from the natural persons that manage its activities), or by individuals that may be identified with a corporation or other business entity."

Tindak kejahatan yang dilakukan Korporasi ini sendiri sering terjadi dalam skala besar dan merugikan masyarakat. Seperti yang dikutip dari The Law Reform Commission of New South Wales, Australia:21

"Corporate crime poses a significant threat to the welfare of the community. Given the pervasive presence of corporations in a wide range of activities in our society, and the impact of their actions on a much wider group of people than are affected by individual action, the potential for both economic and physical harm caused by a corporation is great." Melihat fenomena inilah kemudian muncul tuntutan akan pertanggung jawaban korporasi (corporate liability) di bidang Hukum Pidana.

Menurut Mardjono Reksodiputro ada dua hal yang harus diperhatikan dalam menentukan tindak pidana korporasi yaitu8:

1. Tentang perbuatan pengurus (atau orang lain) yang harus dikonstruksikan sebagai perbuatan korporasi dan kedua tentang kesalahan pada korporasi. Menurut pendapat beliau, hal yang pertama untuk dapat dikonstruksikan suatu perbuatan pengurus adalah juga perbuatan korporasi maka digunakanlah "asas identifikasi" . Dengan asas tersebut maka

\footnotetext{
${ }^{20}$ Lihat kutipan dari The Law Reform Commission of New South Wales dalam Wikipedia, the free encyclopedia, Corporate Crime

${ }^{21}$ Wikipedia, the free encyclopedia, Corporate Crime
} 
perbuatan pengurus atau pegawai suatu korporasi, diidentifikasikan (dipersamakan) dengan perbuatan korporasi itu sendiri.

2. Memang selama ini dalam ilmu hukum pidana gambaran tentang pelaku tindak pidana masih sering dikaitkan dengan perbuatan yang secara fisik dilakukan oleh pembuat (fysieke dader) namun hal ini dapat diatasi dengan ajaran "pelaku fungsional" (functionele dader) . Dengan kita dapat membuktikan bahwa perbuatan pengurus atau pegawai korporasi itu dalam lalu lintas bermasyarakat berlaku sebagai perbuatan korporasi yang bersangkutan maka kesalahan (dolus atau culpa) mereka harus dianggap sebagai kesalahan korporasi.

KUHP yang berlaku saat ini belum mengatur mengenai pertanggungjawaban pidana korporasi dalam arti belum mengenal korporasi sebagai subjek tindak pidana, namun beberapa undangundang khusus di luar KUHP telah mengenal korporasi sebagai subjek tindak pidana selain orang. Beberapa perundang-undangan di luar KUHP yang telah mengatur korporasi sebagai subjek tindak pidana antara lain, Undang-Undang Darurat No. 17 tahun 1951 Tentang Penimbunan Barang yang merupakan undangundang positif pertama yang menggunakan prinsip bahwa korporasi dapat menjadi pelaku tindak pidana.

Undang-undang tersebut kemudian diikuti oleh undangundang lainnya seperti, Undang-Undang No. 7/Drt. 1955 tentang Tindak Pidana Ekonomi, Undang-Undang No. 5 Tahun 1984 tentang Perindustrian, Undang-Undang No. 6 Tahun 1984 tentang Pos, Undang-Undang No. 9 Tahun 1985 tentang Perikanan sebagaimana yang telah diubah dengan Undang-Undang No. 31 Tahun 2004, Undang-Undang No. 7 Tahun 1992 tentang Perbankan sebagaimana yang telah diubah dengan UndangUndang No. 10 Tahun 1998, Undang-Undang No. 8 Tahun 1995 tentang Pasar Modal, Undang-Undang No. 10 Tahun 1995 tentang Kepabeanan, Undang-Undang No. 5 Tahun 1997 tentang

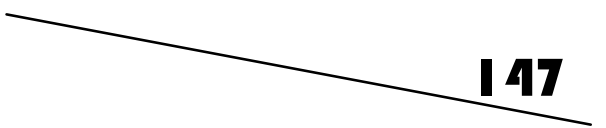


Psikotropika, Undang-undang No. 22 Tahun 1997 tentang Narkotika, Undang-Undang No. 23 Tahun 1997 tentang Pengelolaan Lingkungan Hidup, Undang-Undang No. 5 Tahun 1999 tentang Larangan Monopoli dan Persaingan Usaha Tidak Sehat, Undang-Undang No. 8 Tahun 1999 tentang Perlindungan Konsumen, Undang-Undang No. 31 Tahun 1999 tentang Pemberantasan Tindak Pidana Korupsi sebagaimana telah diubah dengan Undang-Undang No. 20 Tahun 2001, Undang-Undang No. 15 Tahun 2002 tentang Tindak Pidana Pencucian Uang sebagaimana telah diubah dengan Undang-Undang No. 25 Tahun 2003. ${ }^{22}$

Berdasarkan penjelasan di atas, terdapat penyelewengan rumusan hukum tentang korporasi sebagai subyek hukum yang dibenarkan oleh perundang-undangan. Dalam ketentuan umum KUHP jelas tidak mencantum koorporasi sebagai subyek hukum. Namun dalam beberapa perundangan-undangan di luar KUHP mencantum korporasi sebagai subyek hukum.

Oleh Karen itu penulis akan mengnalisis bagaimana korporasi menjadi subyek hukum. Sesuatu dapat menjadi subyek hukum karena 1) memiliki hak dan kewajiban, 2) memiliki kecakapan hukum, dan 3) diakui secara sah oleh hukum. Permasalahan yang kita temukan akan berbeda bila kitamembicarakan tentang korporasi karena pada saat ini, belum terdapatpengaturan tentang korporasi dalam KUHP yang menjadi dasar daripenjatuhan sanksi pelanggaran dan kejahatan. Jadi sangat tidak beralasan apabila menyamakan korporasi dengan "siapa", "barangsiapa", ataupun "siapa pun" yang terdapat dalam KUHP untuk menjatuhkan hukuman yang harus dipertanggungjawabkan terhadap korporasi.

Dalam sistem pidana Indonesia, suatu perbuatan merupakan tindak pidana atau perilaku melanggar hukum pidana hanyalah apabila suatu ketentuan pidana yang telah menentukan bahwa perbuatan itu merupakan tindak pidana. Hal ini berkenaan

22 Barda Nawawi Arief, Kapita Selekta Hukum Pidana, Citra Aditya Bakti, Bandung, 2003, hal. 223-226 
dengan berlakunya asas legalitas sebagaimana ditentukan dalam Pasal 1 ayat (1) KUHP, yang berbunyi : "Tiada suatu perbuatan dapat dipidana kecuali berdasarkan aturan pidana dalam perundang-undangan yang sebelum perbuatan itu dilakukan telah ada."

Ketentuan ini memberi jaminan bahwa seseorang tidak dapat dituntut berdasarkan ketentuan undang-undang secara berlaku surut. Ketentuan ini juga didukung semangatnya dalam Undangundang No. 4 Tahun 2004 tentang Kekuasaan Kehakiman, asas legalitas itu dapat juga dijumpai dalam Pasal 6 ayat (1) UU tersebut, yang berbunyi : "Tidak seorang pun dapat dihadapkan di depan pengadilan selain daripada yang ditentukan oleh undang-undang." 2384

Jadi berdasarkan penjelasan diatas yang dimaksud dengan tindak pidana adalah perilaku yang melanggar ketentuan pidana yang berlaku ketika perilaku tersebut dilakukan, baik perilaku tersebut berupa melakukan perbuatan tertentu yang dilarang oleh ketentuan pidana maupun tidak melakukan perbuatan tertentu yang diwajibkan oleh ketentuan pidana.

Sedangkan perilaku tersebut haruslah dilakukan oleh manusia sebagai subjek hukum yang dikenal dalam KUHP, namun dalam hal ini berdasarkan Pasal 59 KUHP, korporasi sebagai subjek hukum tidak dikenal, bunyi lengkap Pasal 59 KUHP tersebut adalah : " Dalam hal-hal dimana pelanggaran ditentukan pidananya diancamkan kepada pengurus, anggotaanggota badan pengurus atau komisariskomisaris, maka tidak dipidana pengurus, anggota badan pengurus atau komisaris yang ternyata tidak ikut campur melakukan pelanggaran tersebut."

Dalam KUHP Indonesia, tidak terdapat satu pasal pun yang menentukan pelaku tindak pidana yang bukan manusia. Pendirian KUHP bahwa hanya manusia yang dapat dibebani dengan pertanggungjawaban pidana adalah karena adanya adagium actus non facit reum, nisi mens sit rea yang berarti " tiada pidana tanpa

${ }^{23}$ Sutan Remy Sjahdeini, op cit, hal 26

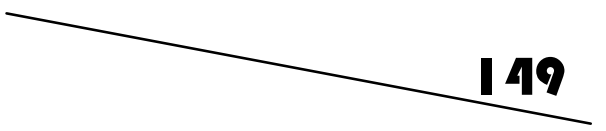


kesalahan", adagium ini dianut secara universal dalam undangundang pidana. Adagium ini berpendapat bahwa seseorang harus memiliki sikap kalbu (state of mind) atau mens rea yang terkait langsung dengan perbuatan itu. Pendapat inilah yang kemudian berpandangan bahwa korporasi yang tidak mempunyai kalbu tidak dapat dibebani pertanggungjawaban pidana. Namun seperti yang kita ketahui, korporasi ada tidak hanya dengan begitu saja, tetapi jelas pasti ada yang mendirikan korporasi itu, dan yang mendirikan korporasi itu yang kemudian memiliki kalbu.

Pemikiran ini yang kemudian melahirkan pendapat bahwa korporasi dapat juga dijadikan sebagai pelaku tindak pidana. Dan seiring dengan perkembangan manusia dan sosial masyarakat pula, maka hukum pun harus mencari cara-cara baru untuk menutupi celah-celah yang mungkin terjadi yang dapat menyebabkan ketidakstabilan ekonomi, sosial dan budaya masyarakat mengingat hukum adalah sebagai payung bagi masyarakat pencari keadilan.

Perkembangan hukum ini juga sejalan dengan perkembangan hukum pidana di negara-negara lain. Dalam undang-undang kejahatan khusus seperti contohnya UU No. 5 Thn 1997 tentang Psikotropika, UU No 15 Thn 2002 jo UU No. 25 Thn 2003 tentang Tindak Pidana Pencucian Uang (Money Laundry), UU No.31 Thn 1999 jo UU No. 20 Thn 2001 tentang Pemberantasan Tindak Pidana Korupsi. Dan dalam RUU KUHP $2004^{24}$ tampak pula telah memberikan pengertiannya terhadap korporasi yang tercantum dalam Pasal 166 sebagai berikut : " Korporasi adalah kumpulan terorganisasi dari orang dan/atau kekayaan, baik merupakan badan hukum maupun bukan badan hukum". Semua undangundang di atas telah memberikan pengertian tentang korporasi yang diambil dari pengertian tentang korporasi di dalam RUU KUHP.

${ }^{24}$ RUU KUHP pada Direktorat Jendral Peraturan Perundang-undangan, Departeman Hukum dan Hak Asasi Manusia, 2004 
Barda Nawawi Arief2586, mengutip dari Nico Keijzer, menuliskan tentang kondisi-kondisi yang akan meletakan korporasi sebagai pelaku sebuah tindak pidana, menurut beberapa aturan hukum di beberapa negara seperti dalam :

a. American Model Penal Code (MPC) - section 2.07.(1) :1

1) Apabila maksud pembuat UU untuk mengenakan pertanggungjawaban pada korporasi nampak dengan jelas dan perbuatan itu dilakukan oleh agen korporasi yang bertindak atas nama korporasi dalam ruang lingkup jabatan/tugas atau pekerjaannya; atau.

2) Apabila tindak pidana itu merupakan suatu pengabaian/pelanggaran kewajiban khusus yang dibebankan kepada korporasi oleh UU; atau

3) Apabila dilakukanny atindak pidana itu dibenarkan/disahkan, diminta, diperintahkan, dilaksanakan, atau dibiarkan/ditolerir secara sembrono oleh dewan direksi atau oleh agen pimpinan puncak yang bertindak atas nama korporasi dalam batas-batas ruang lingkup tugas/pekerjaannya.

b. Dutch Case Law (Yurisprudensi Belanda) :

1) Apabila terjadi pelanggaran terhadap ketentuan UU yang secara khusus ditujukan bagi korporasi, misal korporasi tidak memenuhi syarat-syarat dari suatu izin yang telah diberikan kepadanya. Dengan demikian, korporasi tidak dipandang telah melakukan tindak pidana dalam hal ketentuan UU secara khusus ditujukan kepada individu.

2) Apabila korporasi berkewajiban mencegah terjadinya tindak pidana, tetapi gagal berbuat demikian (misal diskriminasi).

3) Apabila tindak pidana itu berhubungan dengan bidang usaha korporasi yang bersangkutan. Misal pencemaran beberapa hari yang ditimbulkan dari saluran kotoran (the sewage drain) suatu perusahaan/pabrik kimia.

${ }^{25}$ Barda Nawawi Arief, Perbandingan Hukum Pidana, Raja Grafindo Persada, Jakarta, 2002, hal |3|

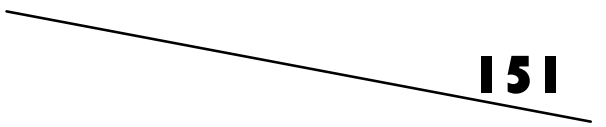


Pendapat-pendapat diatas menerangkan bahwa seiring dengan kemajuan perundang-undangan, para penegak hukum pun mencari kaidah-kaidah baru dalam rangka penegakan hukum tersebut di segala aspek.

Dimana di masa kini, korporasi disebutkan pula dapat dibebani pertanggungjawaban dan dapat dijadikan sebagai pelaku kejahatan. Maka dalam perkembangan hukum pidana Indonesia, ada 3 sistem kedudukan korporasi sebagai pembuat dan pertanggungjawaban korporasi dalam hukum pidana, yaitu : (1) Pengurus korporasi sebagai pembuat dan penguruslah yang bertanggungjawab, (2) Korporasi sebagai pembuat dan pengurus yang bertanggungjawab, (3) Korporasi sebagai pembuat dan yang bertanggungjawab ${ }^{26}$. Berikut ini penjelasannya:

\section{a. Pengurus Korporasi Sebagai Pembuat dan Pengurus yang Bertanggungjawab}

Sistem pertanggungjawaban ini adalah sistem yang dianut oleh KUHP. KUHP mempunyai pendirian bahwa korporasi tidak dapat dibebani pertanggungjawaban pidana dikarenakan korporasi tidak memiliki kalbu dan tidak pula memiliki guilty mind, pengurus korporasilah yang memiliki kalbu sebagai naturlijk persoon yang dapat melakukan kejahatan, maka pengurus korporasi yang bisa diberi pertanggungjawaban pidana. Pendirian KUHP ini termaktub dalam Pasal 59 KUHP.

Ketentuan yang menunjuk bahwa tindak pidana hanya dilakukan oleh manusia adalah Pasal 53 jo Pasal 55 KUHP dan Pasal 372 jo Pasal 374 KUHP, dimana Pasal 53 berbunyi :

1) Percobaan melakukan kejahatan dapat dipidana, apabila maksud akan melakukan kejahatan itu sudah nyata, dengan adanya permulaan membuat kejahatan itu dan perbuatan itu tidak diselesaikan hanyalah oleh sebab hal yang tidak tergantung kepada kehendaknya sendiri.

26 Reksodiputro B Mardjono, Pertanggungjawaban Pidana Korporasi dalam Tindak Pidana Korporasi, Semarang, FH UNDIP, 1989, hal 9 
2) Maksimum pidana pokok yang diancamkan atas kejahatan itu dikurangi sepertiganya dalam hal percobaan.

3) Jika kejahatan itu dapat dipidana dengan pidan mati atau penjara seumur hidup, maka dijatuhkan pidana penjara yang selama-lamanya lima belas tahun.

4) Untuk kejahatan yang telah diselesaikan dan percobaan melakukan kejahatan itu, sama saja pidana tambahannya.

Pasal 55 KUHP berbunyi :

1) Dipidana sebagai si pembuat sesuatu tindak pidana :

a) orang yang melakukan, yang menyuruh melakukan atau yang turut melakukan perbuatan itu ;

b) orang yang dengan pemberian upah, perjanjian, salah memakai kekuasaan atau martabat, memakai paksaan, ancaman atau tipu karena memberi kesempatan, ikhtiar atau keterangan, dengan sengaja menghasut supaya perbuatan itu dilakukan.

2) Adapun tentang orang yang tersebut dalam sub 2 itu, yang boleh dipertanggungjawabkan kepadanya hanyalah perbuatan yang disengaja dibujuk olehnya serta akibat perbuatan itu.

Pasal 372 KUHP berbunyi:

Barangsiapa dengan sengaja dan dengan melawan hukum memiliki barang, yang sama sekali atau sebagian kepunyaan orang lain, dan yang ada padanya bukan karena kejahatan, dipidana karena penggelapan, dengan pidana penjara selamalamanya empat tahun atau denda, sebanyak-banyaknya sembilan ratus rupiah.

Pasal 374 KUHP berbunyi:

Penggelapan yang dilakukan oleh orang yang memegang barang itu karena jabatannya sendiri atau karena pekerjaannya atau karena mendapat upah uang, dipidana dengan pidana penjara selamalamanya lima tahun.

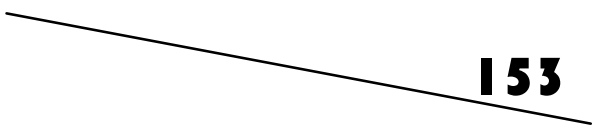




\section{b. Korporasi sebagai Pembuat dan Pengurus yang Bertanggungjawab}

Sistem pertanggungjawaban ini ditandai dengan pengakuan yang timbul dalam perumusan undang-undang bahwa suatu tindak pidana dapat dilakukan oleh perserikatan atau badan usaha (korporasi), akan tetapi tanggungjawab untuk itu menjadi beban dari pengurus badan usaha (korporasi) tersebut. Secara perlahanlahan tanggungjawab pidana tersebut beralih dari anggota pengurus kepada mereka yang memerintahkan, atau dengan larangan melakukan apabila melalaikan memimpin secara sesungguhnya.

Dalam sistem pertanggungjawaban ini korporasi dapat menjadi pembuat tindak pidana, akan tetapi yang bertanggungjawab adalah para anggota pengurus, asal saja dinyatakan dengan tegas dalam peraturan itu. Sistem pertanggungjawaban yang kedua ini sejalan dengan sistem pertanggungjawaban yang pertama namun perbedaannya disini adalah, bahwa hal korporasi sebagai badan usaha yang dapat dijadikan pelaku kejahatan telah dapat diterima, namun dalam hal korporasi melakukan kejahatan, tidak mungkin tanpa kehendak dari pengurusnya.

Munir Fuady, menjelaskan mengenai tanggungjawab direksi dalam hukum perseroan yang berkenaan dengan pelaksanaan fiduciary duty. Menurut Munir Fuady, pada prinsipnya ada 2 (dua) fungsi utama dari direksi suatu perseroan, yaitu :27

1) Fungsi manajemen, dalam arti direksi melakukan tugas memimpin perusahaan.

2) Fungsi representasi, dalam arti direksi mewakili perusahaan di dalam dan luar pengadilan. Prinsip mewakili perusahaan di luar pengadilan memyebabkan perseroan sebagai badan hukum akan terikat dengan transaksi atau kontrak-kontrak yang dibuat oleh direksi atas nama dan kepentingan perseroan.

${ }^{27}$ Munir Fuady, Doktrin-doktrin Modern Dalam Corporate Law\& Eksistensinya Dalam Hukum Indonesia, Citra Aditya Bakti, Bandung, 2002, hal 10. 
Fiduciary duty didefinisikan sebagai suatu tugas dari seseorang yang disebut "trustee" yang terbit dari suatu hubungan hukum antara trustee tersebut dengan pihak lain yang disebut dengan beneficiary, dimana pihak beneficiary memiliki kepercayaan yang tinggi kepada pihak trustee, dan sebaliknya pihak trustee juga mempunyai kewajiban yang tinggi untuk melaksanakan tugasnya dengan sebaik mungkin dengan itikad baik yang tinggi, fair dan penuh tanggung jawab, dalam menjalankan tugasnya atau untuk mengelola harta/asset milik beneficiary dan untuk kepentingan beneficiary, baik yang terbit dari hubungan hukum atau jabatannya selaku trustee (secara teknikal), atau dari jabatanjabatan lain seperti lawyer (dengan kliennya), perwalian (guardian), executor, broker, kurator, pejabat publik, atau direktur dari suatu perusahaan. ${ }^{28}$

Konsep fiduciary duty dalam hukum common law seperti yang dianut Indonesia adalah direksi dalam menjalankan perseroan harus memegang prinsip kehati-hatian, prinsip kepantasan, dan itikad baik karena fiduciary duties ini adalah terbit dari Anggaran Dasar yang disusun bersama antara direksidireksi serta pengurus-pengurus dalam sebuah korporasi. ${ }^{29}$

Dalam UU Perseroan Terbatas, hal mengenai fiduciary duty ini sendiri tersirat dalam Pasal 82 dan Pasal 85 ayat (2). Perseroan sebagai badan hukum dan subjek hukum mempunyai hak dan kewajiban, hak dan kewajiban itulah yang selanjutnya akan dilaksanakan oleh Direksi dan organ pengurus yang ada didalam perseroan tersebut. Direksi merupakan organ yang terdiri dari atas direktur yang tiada lain adalah merupakan subjek hukum beupa orang atau natural persoon/natuurlijk pesoon..$^{30}$

Sehubungan dengan konsep fiduciary duty dalam sistem commom law yang telah penulis sampaikan diatas, disini terdapat

\footnotetext{
${ }^{28} \mathrm{Ibid}$, hal 34.

29 Prahasto. W. Pamungkas, disampaikan sebagai bahan materi mata kuliah Kapita Selekta Hukum Bisnis di Pascasarjana Universitas Pelita Harapan, 2007, Jakarta. Hal.68

${ }^{30}$ I.G. Rai Widjaya, op cit, hal 222
}

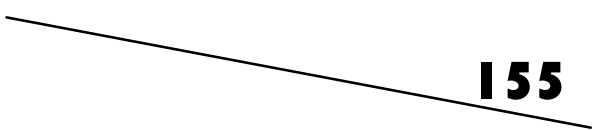


"confidential relation" atau hubungan dasar kepercayaan antara perseroan sebagai badan hukum dengan pengurus sebagai natural person, yang dibebankan tugas dan kewajiban berdasarkan fiduciary ditambah lagi fiduciary tersebut harus dijalankan berdasarkan prinsip kehati-hatian, prinsip kepantasan serta itikad baik untuk mencapai kepentingan dan tujuan perseroan.

\section{c. Korporasi sebagai Pembuat dan yang Bertanggungjawab}

Sistem pertanggungjawaban yang ketiga ini merupakan permulaan adanya tanggungjawab yang langsung dari korporasi. Dalam sistem ini dibuka kemungkinan menuntut korporasi dan meminta pertanggungjawabannya menurut hukum pidana. Halhal yang dapat dipakai sebagai alasan-alasan bahwa korporasi sebagai pembuat dan sekaligus yang bertanggungjawab adalah sebagai berikut:

Pertama, karena dalam berbagai tindak pidana ekonomi atau fiscal, keuntungan yang diperoleh korporasi atau kerugian yang diderita masyarakat dapat sedemikian besarnya sehingga tidak akan mungkin seimbang bilamana pidana hanya dijatuhkan pada pengurusnya saja;

Kedua, dengan hanya memidana pengurusnya saja, tidak atau belum ada jaminan bahwa korporasi tidak akan mengulangi tindak pidana lagi..$^{31}$

Menurut Sutan Remy Sjahdeini, terdapat sistem pertanggungjawaban yang ke- empat setelah terdapat tiga sistem diatas yang dianut dalam pertanggungjawaban korporasi. Sistem yang ke-4 itu adalah : "Pengurus dan korporasi keduanya sebagai pelaku tindak pidana, dan keduanya pula harus memikul pertanggungjawaban pidana". 32

Di negeri Belanda sendiri dengan diubahnya Pasal 15 ayat (1) Wet Delicten 1950 menjadi Undang-undang tanggal 23 tahun 1976 Stb 377 yang disahkan tanggal 1 September 1976 telah membawa 
perubahan terhadap sifat dapat dipidananya korporasi sebagimana diatur dalam sistem hukum pidana Belanda.

Meskipun dalam KUHP Indonesia yang sampai sekarng ini masih dipakai yang masih merupakan warisan pemerintahan Belanda, namun RUU KUHP yang baru sudah meletakkan pengertian tentang korporasi yaitu dalam Pasal 45 sampai dengan Pasal 50 yang mana korporasi dapat dijadikan sebagai pelaku kejahatan dan dapat pula dibebani pertangungjawaban. Dari beberapa pasal-pasal dalam RUU KUHP yang mana menjelaskan tentang keberadaan korporasi dapat dijadikan pelaku tindak pidana, dapat disimpulkan sebagai berikut :

1) Bahwa secara prinsip dalam RUU KUHP tersebut telah diterima konsep korporasi sbagai badan hukum yang dapat dijadikan subjek dalam hukum pidana;

2) Dengan demikian badan hukum dapat dituntut dan di jatuhi hukuman pidana;

3) Tindak pidana yang dapat dipertanggungjawabkan kepada badan hukum adalah semua perbuatan yang termasuk tindak pidana yang dilakukan oleh orang-orang yang mempunyai kedudukan fungsional (functioneel daders) dalam badan hukum yang melakukan perbuatan itu dalam lingkungan usaha dari badan hukum sesuai dengan anggaran dasarnya;

4) Tidak semua peraturan perundang-undangan dapat diterapkan atas badan hukum, misalnya tidak mungkin menerapkan sanksi pidana penjara atau pidana mati atas badan hukum. Bila dilihat dari rumusan beberapa pasal tentang korporasi dalam RUU KUHP diatas, kita harapkan di masa mendatang kejahatan-kejahatan oleh korporasi sudah dapat diambil tindakan oleh pemerintah maupun oleh badan yang berwenang.

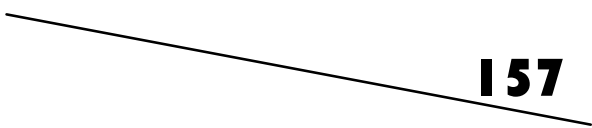




\section{Penutup}

Berdasarkan penjelasan di atas, maka dapat disimpulkan sebagai berikut:

1. Korporasi adalah perikatan beberapa orang yang bersepakat dengan tujuan mencari keuntungan dan diakui keberadaannya secara hukum (berbadan hukum).

2. Korporasi sebagai subyek hukum pidana dapat dipersamakan dengan manusia. Karena di dalamnya terdapat hak dan kewajiban yang diberikan oleh hukum, dan karenanya kecakapan korporasi juga dipersamakan dengan kecakapan manusia yang terlibat di dalamnya.

\section{Daftar Pustaka}

Abdul Kholiq, Hukum Pidana (Buku Panduan Kuliah), Fakultas Hukum Universitas Islam Indonesia, Yogyakarta, 2002

Andi Hamzah, Asas-Asas Hukum Pidana, Yarsif Watampone, Jakarta, 2000.

Andi Hamzah, Naskah Akademik Rancangan Undang-Undang Kitab

Undang-Undang Hukum Acara Pidana, Paper Panel Diskusi 27 tahun KUHAP, Indonesia Room, Hotel Shangri-La, Jakarta, 26 Nopember 2008

Barda Nawawi Arief, Kapita Selekta Hukum Pidana, Citra Aditya Bakti, Bandung, 2003

Barda Nawawi Arief, Perbandingan Hukum Pidana, Raja Grafindo Persada, Jakarta, 2002.

Hyman Gross, A Theory of Criminal Justice, Oxford University Press, New York, 1979

Moeljatno, Kitab Undang-Undang Hukum Pidana, PT Bumi Aksara, Jakarta, 2001

Munir Fuady, Doktrin-doktrin Modern Dalam Corporate LawE Eksistensinya Dalam Hukum Indonesia, Citra Aditya Bakti, Bandung, 2002 
Nyoman Serikat Putra Jaya, Beberapa Pemikiran Ke Arah Pengembangan Hukum Pidana, PT Citra Aditya Bakti, Bandung, 2008

Oemar Seno Adji, Peradiolan Bebas Negara Hukum, Erlangga, Jakarta, 1980

P.A.F. Lamintang dan Djisman Samosir, Hukum Pidana Indonesia, Sinar Baru, Bandung, 1990.

Prahasto. W. Pamungkas, disampaikan sebagai bahan materi mata kuliah Kapita Selekta Hukum Bisnis di Pascasarjana Universitas Pelita Harapan, Jakarta, 2007.

R. Soesilo, Kitab Undang-undang Hukum Pidana, Ctk. Ulang, Politeia, Bogor, 1996.

Reksodiputro B Mardjono, Pertanggungjawaban Pidana Korporasi dalam Tindak Pidana Korporasi, Semarang, FH UNDIP, 1989.

RUU KUHP pada Direktorat Jendral Peraturan Perundangundangan, Departeman Hukum dan Hak Asasi Manusia, 2004.

Soetan. K. Malikoel Adil dalam Muladi dan Dwidja Priyatno, Pertanggungjawaban KorporasiDalam Hukum Pidana, STHB, Bandung, 1991.

Sutan Remi Sjahdeini, Pertanggungjawaban Pidana Korporasi, Grafiti Pers, Jakarta.

Teguh Prasetyo dan Abdul Halim Barkatullah, Politik Hukum Pidana, Ctk. Pertama, Pustaka Pelajar, Yogyakarta, 2005.

The Law Reform Commission of New South Wales dalam Wikipedia, the free encyclopedia, Corporate Crime.

Tjipto Soeroso, Hukum Pidana Khusus-Materi: Hukum Pidana Perekonomian, Wikipedia, the free encyclopedia, Corporate Crime.

Wikipedia, the free encyclopedia, Corporate Crime, diambil dari Wikipedia, the free encyclopedia, Pertanggungjawaban Korporasi, diambil dari

Rusmana,SH, Pertanggungjawaban Korporasi dalam Tindak Pidana Perikanan, http://www.solusihukum.com/artikel/artikel45.php

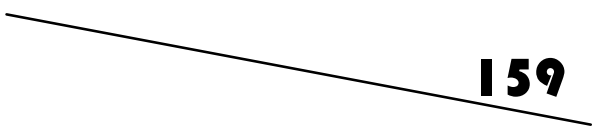


Fakultas Hukum Universitas Diponegoro, 1990. http://www.solusihukum.com/artikel/artikel45.php http://en.wikipedia.org/wiki/Corporate_crime http://id.wikipedia.org/wiki/Pertanggungjawaban_korporasi 